\title{
Text Comprehension and Study Method Acquisition for Students with Specific Learning Disorder: Development and First Application of the SUST Program
}

\author{
Amalia Lavinia Rizzo, ${ }^{1}$ Marianna Traversetti ${ }^{2}$ \\ 1. Roma Tre University, Rome, 00185, Italy \\ 2. University of L'Aquila, L'Aquila, 67100, Italy
}

\begin{abstract}
In this paper we describe an educational program for the development of the study method for students with specific learning disorders (SLD) and a first Italian application on a small sample of fifth grade students. This experience was aimed at collecting useful data precisely to review and improve the above-mentioned program. A particularly relevant problem was identified looking at the anthropological dimension of the capability learning and the need for students to acquire the learning to learn ability. Specifically, it is about the low levels of text comprehension in Italian schools and its consequences on the study activities. Within the inclusive perspective and taking into account the effective didactic strategies in the evidence-based education (EBE) perspective, the project created and tested a teaching kit (SUST) for the fifth classes of the primary school, at-tended by students with SLD. This experimental framework was conducted following the Design Based Research methodology. It also focused on the training of teachers within the intervention classes. The positive results of SUST application open a constructive scenario for the definition of intervention programs aimed at improving text comprehension and study skills of students with SLD. This program should be tested in a wider context of schools.
\end{abstract}

Science Insights Education Frontiers 2021; 9(1):1143-1159.

Doi: 10.15354/sief.21.or039

How to Cite: Rizzo, A. \& Traversetti, M. (2021). Text comprehension and study method acquisition for students with SLD: Development and first application of the SUST program. Science Insights Education Frontiers, 9(1):1143-1159. 
Rizzo \& Traversetti. Learning for Students with Specific Learning Disorder in Italy.

Keywords: Inclusive Education, Reciprocal Teaching, Student with Specific Learning Disorder, Italian School

About the Author: Marianna Traversetti, Researcher in Special Education, University of L'Aquila, L'Aquila, 67100, Italy.E-mail: marianna.traversetti@univaq.it

Correspondence to: Amalia Lavinia Rizzo, Researcher in Special Education, Roma Tre University, Rome, 00185, Italy.E-mail: amalia.rizzo@uniroma3.it

Conflict of Interests: None.

(C) 2021 Insights Publisher. All rights reserved.

(c) (i) (S) Creative Commons Non Commercial CC BY-NC: This article is distributed under the terms of the Creative Commons Attribution-NonCommercial 4.0 License (http://www.creativecommons.org/licenses/by$\mathrm{nc} / 4.0 /$ ) which permits non-commercial use, reproduction and distribution of the work without further permission provided the original work is attributed by the Insights Publisher 


\section{Introduction}

T $\mathrm{N}$ this paper we describe the program Strategies for Understanding and Studying the Text (SUST) developed to promote the study method for students with specific learning disorders (SLD) $)^{\underline{1}}$ and we illustrate its first application on a small sample of fifth grade students of primary school in Italy.

The capability approach ${ }^{2}$ has been an imperative and innovative reference for the development of SUST in an inclusive way.

The promotion of the study method for students with special learning disorders-SLD is essential to enable them to learn in a lifelong learning $\underline{\underline{3}}$ perspective. In this sense, it is closely linked to the capability approach as relevant to reflect on educational practices, in a generative and inclusive perspective.

As is well known, the capability approach has developed in the areas of political philosophy and economic perspectives of welfare. It is an innovative approach to assess the well-being of people and social justice. This assessment takes into account the individual's substantial freedom to act on the basis of values and opportunities.

The capability approach outlines a complex vision of human development. It considers as the center of its reasoning the economic and anthropological dimensions.

This last dimension identifies individual well-being as a process that aims to affirm and enhance the individual potential, in logic of equality of opportunity and social justice.

According to Sen, the role of capabilities correlates directly with the wellbeing and freedom of man and indirectly with social change and economic production. This approach encourages society to stimulate and promote the internal individual capabilities ${ }^{\underline{4}}$ of each person through education, support and family and social care within an ethical framework based on the right to equality, equal opportunities and education.

The perspective we intend to follow here frames the capability approach as an overall vision that provides an interpretative-methodological key useful to offer concrete answers to the many aspects emerging around the issue of inclusive schools.

In particular, it reflects on the ability of the capability approach to respond to the heterogeneity of students, without attributing difficulties exclusively to the characteristics of the individual, but in relation to the actual freedom of choice, life, relationships and study that are really offered.

In this context, placing and defining the right to study in the light of the logic of capabilities means avoiding labeling and "building" schools in which contextual, environmental and personal factors interact to determine a positive functioning of the student with SLD.

In fact, students with SLD are entitled to the fundamental freedoms that allow them to be learners on a basis of equality. Equality is civic, but which is also completed as equality of education.

From this perspective, Sen's ethical-normative approach correlates with the impulse to achieve an inclusive environment by producing changes that enhance opopportunities for freedom and well-being. 
Therefore, school policies for inclusion are called to expand and to enhance the development of students' capabilities by translating resources into a real and substantial freedom.

In this sense, in a heterogeneous class attended by students with SLD, it is necessary to have a greater quantity and quality of effective environmental factors to promote the functioning of these students, that is, what each of them is able to achieve (Sen, 1999). Otherwise, the learning disadvantage can be conceived as a real limitation of capabilities $^{\underline{5}}$.

The right to study is not always reaffirmed, especially for students with SLD for whom "knowing how to study" represents the vital drive to flourish themselves, their own abilities, as free and responsible beings.

In the promotion of the study method, also Sen's reflection about agency comes into play. Sen defines it as a process aimed at producing a change in the person, based on the values he nurtures and the goals he sets himself (Sen, 2001).

Agency is one of the aspects that characterize the study method, as it translates into the person's ability to be active in own learning.

In fact, "capacitating does not lie (so much) in the resources to be mobilized, but in the mobilization of these resources" (Boterf, 1995).

If the principles outlined above are valid for a just society, the same is true for the school that recognizes the individual learning potential of each student with SLD.

Consequently, in the inclusive school, teachers have to support the agency of students with SLD and to guide the development of a study methodology, establishing a virtuous circle in the teaching/learning process.

\section{Materials and methods}

\section{Effective Teaching Strategies for Understanding and Studying the Text}

Before developing SUST program, the research team identified the most effective teaching strategies to reduce and/or compensate the specific difficulties of the students with SLD.

The strategies identified are set out below.

Graphic organizers are visual aids that allow the reader to get an idea of the con-tent of the text. They show the conceptual cruxes or rather the main and secondary information, and the causal relationships between the events narrated or described, as well as the relationships between them. They have an effect size (ES) $\underline{6}$ of 0.26 (Okkinga et al., 2018).

Graphic organizers are particularly useful to organize concepts to be learned through informational-expository texts relating to disciplines of primary and secondary schools (Novak, 2001). 
Graphic organizers include: concept and mind maps, colored highlighting of parts of the text, underlining, use of symbols, etc. (Hattie, 2009). In particular, concept maps have been shown to be very effective devices with an ES of 0.55 (Hattie, 2009).

The summarizing organizers make it possible to produce a text similar to the source text so that it can be studied or analyzed by eliminating information considered secondary and superfluous. The aim is to make a synthesis of the most important contents (Benvenuto, 1987).

The ability to summaries is a strategic process of elaboration. It requires a specific articulation of the didactic proposal: first, the teacher shows how to identify the most important information through the modelling and, subsequently, how to summaries it. In a third phase, the student tries to perform the two previous actions autonomously, supported by the teacher's feedback.

During this phase, the student is called upon to: eliminate secondary information through precise activities, such as: identification of the most important information and of the key concept(s); highlighting of key words; synthesis. Thus, like graphic organizers, the summarizing organizers stimulate metacognition and selfregulation, and optimize the quality of the student achievements relative to understanding, organizing and remembering the studied material (Bonaiuti, 2014).

Indeed, the use of these organizers has positive effects with regard to summary writing skills and content memorization (NICHD, 2000).

The summarizing organizers are often employed in combination with other teaching strategies, as in the case of the reciprocal teaching (Rosenshine \& Meister, 1994).

Reciprocal teaching is a multiple strategy (Davis, 2013) that actively engages the teacher and the student in a co-construction of meaning of the text.

Developed for students at risk of educational failure and also considered effective for those with learning disabilities (Mitchell, 2014), reciprocal teaching consists of four individual strategies (Palincsar \& Brown, 1984):

- Making predictions about the content of the text, before reading it (predicting);

- Clarifying unfamiliar words, new concepts, and idiomatic expressions (clarifying);

- Asking questions by recalling explicit and implicit information (questioning);

- Summarizing by identifying, paraphrasing and integrating the information (summarizing).

Actions related to the strategies are initially presented by the teacher through modelling and thinking aloud and, subsequently, are conducted independently by the student.

Hattie (2009) summarized an ES value of 0.74. More recently, Lee and Tsai (2017) evaluated the effectiveness of the strategy for students with specific poor comprehension $^{7}$ who achieve better learning outcomes than students who received regular instruction $(\mathrm{ES}=0.86)$.

These strategies were grouped in the SUST teaching kit and applied on a repertoire of texts to be offered in fifth-grade primary classes attended by students with SLD. 


\section{SUST: A Program for Understanding and Studying a Text}

SUST is designed as an educational resource to support teaching intervention in fifthgrade primary schools. It consists of two workbooks for student - one for the application of reciprocal teaching, the other for graphic and summarizing organizers.

Following the approach pioneered in Italy by $\mathrm{SApIE}^{\underline{\varepsilon}}$ (Calvani \& Chiappetta, 2019), the workbooks collect both the repertoire of texts and the activities useful to apply the teaching strategies.

The workbooks guide the students by providing them with the necessary indications for their completion, such as: the explanation of the activity to be carried out on the text, the exemplification of the assignments, the questions they must ask themselves for the use of reciprocal teaching, the strategies they must activate for the use of graphic and summarizing organizers, the spaces for writing the answers, as well as the incentives to feed-back between the students themselves. Each student has a personal copy of the workbooks.

The texts in SUST are narrative and expository. The narrative texts are related to various literary prose genres and, although they tend to present events that are generally close to reality, they are not limited to the documentation of a true or likely reality.

The expository typology of texts has an argumentative function, or rather it is based on the intention to provide competencies or to propose and discuss thesis.

The texts were chosen and adapted for students with SLD on the basis of precise lexical, syntactic and graphic criteria (Traversetti \& Rizzo, 2020).

\section{The Section of SUST Dedicated to Reciprocal Teaching}

The section of the teaching kit for reciprocal teaching consists of a repertoire of 20 texts ( 8 narrative and 12 informative-explanatory), and the description of the relevant teaching activities.

In particular, the 8 narrative texts refer to the subject of Italian language, while the 12 explanatory texts refer to the following subject: History (2 texts), Geography (3), Science (3), Civic Education (2), and Technology (2).

The teaching activities for each text are summarized in a visual form. The time needed is indicated. In particular, the activities concern individual work, pair work and class discussion. The individual work concerns the development of the steps related to the strategies of: making predictions, catching unknown words and searching for their meaning, asking questions about the content, producing summaries.

Following the example of SApIE's Reading Comprehension-Reciprocal Teaching program (Calvani \& Chiappetta, 2019; Rizzo et al., 2020), there is also a fifth phase to develop inferential understanding of the text. Each phase is declined on the basis of one or more standard questions for each text (Table 1). 
Table 1. Phases of Reciprocal Teaching and Related Guide to Questions.

\begin{tabular}{l} 
Predicting \\
"What do you think the text will be about?" \\
\hline Clarifying \\
\hline "Are there words you do not know the meaning of?" \\
\hline Questioning \\
"What do you think is the most important information?". If you cannot answer, ask yourself: "Who? What? \\
When? Where? How?" \\
\hline Summarizing \\
\hline "How could you say, in a few words, the point of the story?" \\
\hline Understanding what the text does not say \\
What is the moral of the story? "What can you learn from this story?" "What did you understand that the text \\
does not say?"
\end{tabular}

Specifically, the activities foresee that, on the first three texts of each type, the students observe the cognitive modelling of the teacher. For the subsequent texts, the modelling is gradually reduced, taking into account the progress of the skills gradually acquired by the students and monitoring the process of using the strategy themselves.

Once the teacher's modelling is over, the students carry out work in pairs, within a maximum time limit of 15 minutes in which one of the two students, or both, alternately write the summary in the workbook. During this work, the teacher uses feedback (ES $=0.73$; Hattie, 2009) to confirm the correctness of the answers, showing if there is a need to improve them. For students with SLD, this corrective feedback is characterized in terms of indications of useful guidelines for completing or integrating the task, through alternative ways of working that reduces the cognitive load (Sweller, 1988). Following the pair work, the class discussion involves listening to the summaries produced by the various pairs, intervening when a different solution is proposed, in order to negotiate the best summary to write in the workbook.

\section{The Section of SUST Dedicated to Graphic and Summa- rizing Organizers}

The section of the teaching kit for the application of the strategies of graphic and summarizing organizers consists of a workbook with 21 explanatory texts: History (n.6); Geography (n.6); Science (n.5); Technology (n.2); Civic Education (n.2).

With regard to graphic organizers, the section includes the following activities: highlighting parts of the text in color and drawing up concept maps. With regard to summarizing, the section includes the following activities: identification of key words, elaboration of notes in the margins of the text and production of paraphrases. The graphic organizers are applied to a total of 11 texts, and the summarizing organizers to 10 texts. 
The activities proposed for these texts are both individual and in pairs.

\section{A First Application of SUST in Italian Schools}

The SUST program was applied on a small sample of Italian schools as a pilot study, in order to revise the program and improve materials and application methods.

To this end, the Design Based Research (DBS) method (Dede, 2005) was used to arrive at an 'artifact', also of an organizational nature (Simon, 1969).

A non-probabilistic sample (Cohen et al., 2007), was made up of three fifth classes of Italian primary schools, three of which were intervention classes and two parallel classes with control functions, for a total of 115 students and 10 teachers (6 subject-teachers and 4 support-teachers).

The students were distributed as follows: 24 students with SLD and 51 other students in the intervention classes; 12 students with SLD and 28 other students in the parallel classes.

\section{Teacher Training}

The project also provided training to enable teachers to use SUST. The training referred to the most appropriate ways of assessment of learning, as well as to the relevant compensatory and dispensatory measures to be taken for students with SLD $\stackrel{9}{\text {. The training }}$ took into account the models considered to be able to contribute effectively to the acquisition of adequate teaching expertise: visible learning (Hattie, 2017), which is characterized by interventions on teachers mind frame and video modelling.

\section{Survey Instruments}

As is well known, in the field of inclusive education, data collection responds to the need to understand an educational phenomenon characterized by a high degree of complexity. Therefore, a mixed-method approach (Trinchero, 2002) was preferred. The requests of control class teachers who were not willing to devote much time to the administration of tests were also taken into account. For this rea-son, the tests were divided into common tests (for all classes) and in-depth tests (only for the intervention classes). The "common" tests are the MT Tests (Cornoldi et al., 2017) and the Metacognitive Questionnaire/QMeta (La Marca et al., 2019). The 'in-depth' tests are described in Table 2 .

Here, we present the results of a common test, the QMeta Metacognitive Questionnaire, and of an in-depth test, the Structured Interview with Teachers $\underline{10}$. With particular reference to the intervention classes, the two instruments highlight the views of both students and teachers about the importance of teaching and learning specific study strategies with high inclusion potential. They also bring out the critical points of the research project.

\section{Results}


Table 2. The Use of Metacognitive Strategies According to the Students within the Intervention Classes.

\begin{tabular}{|c|c|c|}
\hline Timing & Description & Reasons for the Choice \\
\hline In \& Out & $\begin{array}{l}\text { Narrative and } \\
\text { informative- } \\
\text { expository text } \\
\text { study evaluation } \\
\text { form }\end{array}$ & $\begin{array}{l}\text { At the beginning of the year, the form was proposed before the start of the } \\
\text { training session in order to support the teachers of the intervention classes } \\
\text { in analyzing the level of comprehension of the study text of their students. Its } \\
\text { use enabled teachers both to understand the need for targeted action for } \\
\text { students' acquisition of study strategies and to motivate themselves for } \\
\text { specific training. At the end of the school year, it seemed appropriate to re- } \\
\text { propose the same form so that teachers could monitor the progress of their } \\
\text { students, with reference to the initial ones, following the educational pathway } \\
\text { undertaken. }\end{array}$ \\
\hline In \& Out & $\begin{array}{l}\text { Evidence of } \\
\text { summary }\end{array}$ & $\begin{array}{l}\text { This test was chosen in order to understand the impact of learning about text } \\
\text { comprehension on the ability to synthesize. It was Initially proposed to all } \\
\text { classes but later it was carried out only by the teachers of the intervention } \\
\text { classes. The other teachers considered their time commitment too heavy } \\
\text { and so their tests were not available }\end{array}$ \\
\hline $\begin{array}{l}\text { In } \\
\text { Progress }\end{array}$ & $\begin{array}{l}\text { Scheduled ques- } \\
\text { tions }\end{array}$ & $\begin{array}{l}\text { During the didactic intervention, the programmed questions were considered } \\
\text { a test strictly related to the didactic path proposed in the intervention clas- } \\
\text { ses. They were therefore considered necessary in order to check whether } \\
\text { they could really be used, both as compensatory tools for students with SLD } \\
\text { and as a means of assessment for all the other students, within the frame- } \\
\text { work of the action schemes and the teaching and assessment strategies } \\
\text { proposed to the teachers of the intervention classes during the training. } \\
\text { Special criteria were also provided for assessing questions. }\end{array}$ \\
\hline $\begin{array}{l}\text { In } \\
\text { Progress }\end{array}$ & $\begin{array}{l}\text { Unstructured } \\
\text { face-to-face } \\
\text { interviews with } \\
\text { teachers }\end{array}$ & $\begin{array}{l}\text { Unstructured interviews were made available and carried out at the request } \\
\text { of teachers of intervention classes only, in order to clarify any doubts about } \\
\text { the application of the proposed strategies. These interviews were recorded } \\
\text { and transcribed. }\end{array}$ \\
\hline Out & $\begin{array}{l}\text { Checklist for } \\
\text { observing the } \\
\text { study of a stu- } \\
\text { dent with SLD }\end{array}$ & $\begin{array}{l}\text { At the end of the school year, the proposal to observe and describe in detail } \\
\text { the study methods of students with SLD was considered important in order } \\
\text { to collect useful data to characterize the situation in all its complexity (What } \\
\text { compensatory tools did they use in their studies? What dispensatory } \\
\text { measures have they adopted? What study strategies did they prefer?). Like } \\
\text { the summary test, this one was also proposed to all classes, but its admin- } \\
\text { istration was accepted and carried out only by the teachers of the interven- } \\
\text { tion classes. }\end{array}$ \\
\hline Out & $\begin{array}{l}\text { Structured inter- } \\
\text { view with teach- } \\
\text { ers }\end{array}$ & $\begin{array}{l}\text { To detect the specific point of view of the teachers of the intervention clas- } \\
\text { ses, activating a reflexive action also attentive to the emotional aspects of } \\
\text { the students with SLD, was necessary to define the real contexts in which } \\
\text { the didactic kit was applied with the relative strategies from a qualitative } \\
\text { point of view. It was also considered that this allowed the ecological context } \\
\text { of the research to be enhanced, opening up to the knowledge of unexpected } \\
\text { data, according to the principle of serendipity (Lucisano \& Salerni, 2002). }\end{array}$ \\
\hline
\end{tabular}

\section{The Qmeta Metacognitive Questionnaire}

The QMeta questionnaire was used in order to detect the metacognitive strategies that the students employ in understanding the text. In the questionnaire, the students expressed the extent to which the statements $\underline{\underline{I I}}$ corresponded to their person-al way of reading, understanding and studying a text, using a rating scale from 0 to 2 .

The QMeta provides the opportunity to obtain partial and comprehensive scores. The partial scores are related to critical aspects that should be investigated for a 
targeted teaching activity. Comprehensive scores are an index that allows an easy evaluation of the metacognitive aspects implemented by the students while reading. They offer a single figure that allows comparisons to be made between students with and without SLD certification, within the same class group.

The total time within which each test had to be completed was not established be-fore, but all the classes completed it within ten minutes. Students with SLD did not need additional time, as they were able to read the items with the help of the teacher.

For the students with SLD as well as for the other students, two repeatedmeasures analysis of variance (ANOVA) models were conducted on the two types of classes involved.

Responses to the QMeta metacognitive questionnaire, whose aggregate data are reported here, showed that, at the end of the year, students with and without SLD in the intervention classes report using more metacognitive strategies for comprehension and text study than at the beginning of the year.

The analysis of the data for the students with SLD in the intervention classes shows that the teaching action contributed positively $(\mathrm{F}=122.645 ; \mathrm{p}<0.001 ; \mathrm{ES}=$ 0.192 ) to the students' employing metacognitive strategies, such as: anticipation, identification of the most important information, summarizing and discussing with others. As shown by the post-test, the answers reveal a significant improvement both with respect to their initial performance $(\mathrm{M}=3.083 v s .12 .833 ; \mathrm{p}<0.001)$ and with respect to the performance of the students of the control classes at the end of the school year $(\mathrm{M}=$ 12.833 vs. $\mathrm{M}=6.500 ; \mathrm{p}<0.001$ ) (Table 3 and Figure 1).

The analysis of the data shows that for the students without certification of SLD in the intervention classes the didactic action contributed positively to the use of metacognitive strategies $(\mathrm{F}=336.310 ; \mathrm{p}<0.001$; $\mathrm{ES}=0.212)$. At the post-test, the answers show a significant improvement both with respect to their initial performance (M $=4.820$ vs. $12.920 ; \mathrm{p}<0.001)$, and with respect to the answers of the students of the control classes at the end of the school year $(\mathrm{M}=12.920$ vs. $\mathrm{M}=6.139 ; \mathrm{p}<0.001)$ (Table 4 and Figure 2).

\section{The Structured Interview with the Teachers}

Following the administration of the exit tests, the Structured Interview addressed to the teachers of the intervention classes showed that the project was considered an excellent opportunity for professional growth. This was particularly due to the fact that the teaching strategies present in the SUST made it possible to increase the students' knowledge and skills in an evident and parallel way. This facilitated the inclusion of those with difficulties, resulting in a general level of competence in understanding and studying linguistic, historical-geographical and scientific texts.

In particular, the teacher of the class which obtained the best result for students with SLD stressed that the activity in the reciprocal teaching section of the kit helped them to overcome their difficulties and proved to be a powerful tool for inclusion. Students with SLDs are in fact "progressively improved in the process of text comprehend- 


\section{Table 3. Answers of Students with SLD (QMeta Questionnaire).}

\begin{tabular}{lllll}
\hline Time & Class & Mean & SD & N \\
\hline Post & Intervention & 12,833 & 2,334 & 24 \\
\cline { 2 - 5 } & Parallel & 6,500 & 2,236 & 12 \\
\hline \multirow{2}{*}{ Pre } & Intervention & 3,083 & 1,530 & 24 \\
\cline { 2 - 5 } & Parallel & 4,250 & 1,712 & 12 \\
\hline
\end{tabular}

Table 4. Students without Certification of SLD (QMeta Questionnaire).

\begin{tabular}{lllll}
\hline Time & Class & Mean & SD & N \\
\hline Post & Intervention & 12,920 & 1,872 & 50 \\
\cline { 2 - 5 } & Parallel & 6,139 & 2,244 & 36 \\
\hline \multirow{2}{*}{ Pre } & Intervention & 4,820 & 1,320 & 50 \\
\cline { 2 - 5 } & Parallel & 5,111 & 2,376 & 36 \\
\hline
\end{tabular}

sion, in particular in asking questions, hypotheses, arriving at syntheses and managing time" (Traversetti \& Rizzo, 2019).

Moreover, it emerged that "some of them, who in collective discussions related to the reading of a text initially failed to make relevant interventions, were more confident in intervening" (Traversetti \& Rizzo, 2019).

With regard to the activities related to graphic and summarizing organizers, the teachers of 2 out of 3 classes considered it appropriate to revise the Personalized Learning Plans (PDPs), monitoring them in itinere (in progress) and redesigning them in order to take into account the use of SUST strategies.

With regard to the critical points that emerged, the teachers of 2 out of 3 intervention classes revealed that the most complex phase was that of producing the summary in 20 words, especially for students with SLD. These students, in fact, were more focused on the game of finding and counting the 20 words within which to write the summary rather than on summarizing the content.

The teaching strategy which has proven to be the most effective in solving this particular problem is slowing down and spending a lot of time reading and care-fully analyzing the various summaries.

\section{Discussion}

Despite the small sample size, we can be assured that the project had positive results in relation to the development of text comprehension by students with SLD and other students. Following the intervention, in fact, students with difficulties achieved better 


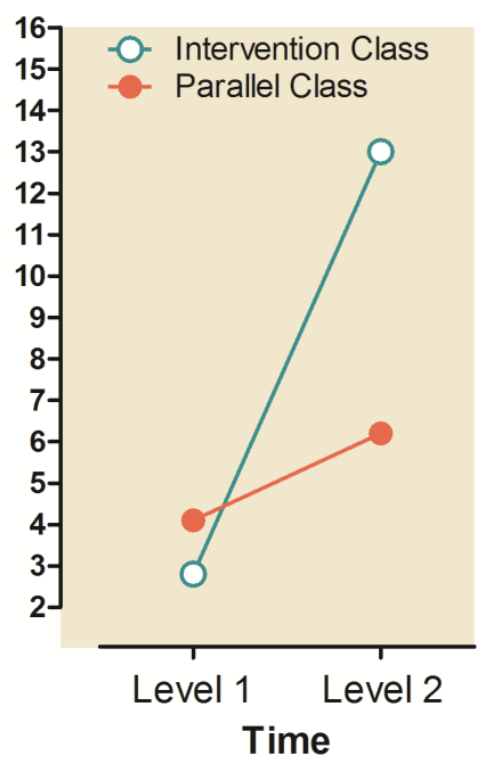

Figure 1. Use of Metacognitive Strategies According to Students with SLD into the Involved Classes, at the Beginning and End of the School Year.

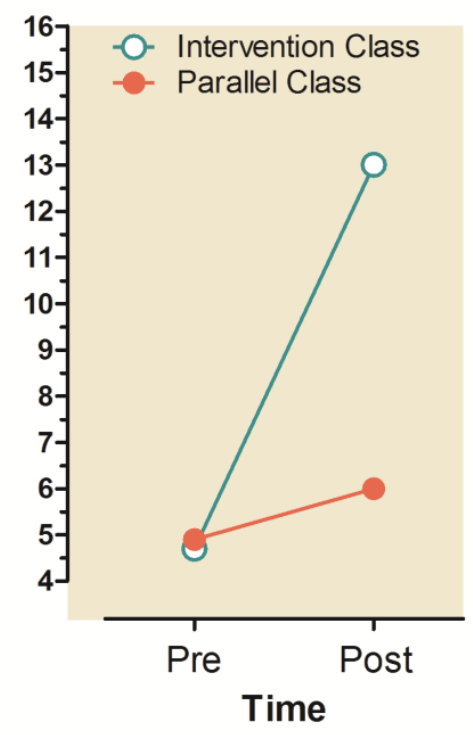

Figure 2. The Use of Metacognitive Strategies According to Students without SLD Certification into the Involved Classes, at the Beginning and End of the School Year. 
learning outcomes than students who received the usual instruction (Chall \& Jacobs, 2003; Lee \& Tsai, 2017).

The common activities always proposed to both students with SLD and their peers showed a clear improvement in their ability to employ metacognitive strategies. At the end of the project, in fact, these students stated that they used the new metacognitive strategies more frequently and more consciously than at the beginning of the year and also than students in the other three classes.

This leads us to believe that the teaching activities carried out in the intervention classes had a strong inclusive value, improving the learning and participation of all the students, with and without SLD. In fact, all students showed great interest and enjoyment in using the different new strategies. The students considered these activities out of the ordinary.

The level of inclusiveness of the intervention classes was enhanced by the redesign of the Personalized Learning Plans (PDPs) for students with SLD and the class programming. Following the training, the effective teaching strategies of the SUST were included to promote text comprehension for the study of different subject.

Despite some difficulties, therefore, it seems possible to state that the methodological approach of the training has made it possible to lay the foundations for effectively combining research with teaching, according to a sustainable and useful intervention model to be replicated in other situations.

The research outlines possible applications in broader scenarios. Considering the usefulness of the proposal, the project should be continued in order to improve the development of the SUST and extend it to a repertoire of different types of texts: not only narrative and explanatory, but also regulatory and argumentative.

In the development of the overall intervention, it will also be necessary to take into account the need to apply the teaching strategies over a longer period of time, probably from November to May, as well as suggested by teachers.

\section{Notes}

1. For further details, see: Borkowski, Muthukrishna, 2011; Chiappetta Cajola, Traversetti, 2016, 2018.

2. For further information, see: Nussbaum, Sen, 1993; Sen, 1982, 1992, 2000, 2009; Nussbaum, 2011.

3. To deepen, see: Delors, 1997; Council of the European Union, 2018.

4. Capabilities can be divided into: internal capabilities (intellectual, emotional, personal, perception and movement) and combined capabilities (the result of interaction with the living environment). Capabilities are thus the sum of internal capabilities and the social, political and economic conditions in which people's functioning can be determined. 
5. Sen illustrates a similar concept by comparing the choice of a wealthy person to abstain from food with the contingent situation of a person suffering from hunger (Sen, 1999). The former possesses the essential capabilities to choose to fast, the latter is deprived of these capabilities and is substantial-ly disadvantaged.

6. It is a standardised indicator representing a measure of the strength of an investigated phenomenon. If the number is less than zero, the result is negative, if it is higher, it indicates a positive result. A value between 0 and 0.10 has a small effect, up to 0.30 has a medium effect and above 0.50 has a large effect. "The threshold above which the consequential effect of a given intervention visibly shows its effects is from ES=0.40" (Bonaiuti, 2014, pp15).

7. Those who have difficulties in the specific domain of text comprehension at the transition between the third and fourth grade of primary school (Chall \& Jacobs, 2003).

8. SApIE is the association that in Italy promotes the dissemination of evidence-informed learning strategies, www.sapie.it.

9. The "Guidelines for the right to study of students and students with specific learning disorders" $(M I U R, 2011)$ provide operational indications to teachers and guide them to the use of appropriate compensatory and dispensatory measures. Compensatory and dispensatory measures include: use of voice synthesis, calculator, diagrams and maps, forms, etc.; reading by others; additional time during tests.

10. For other results see: Traversetti, Rizzo, 2020 and Rizzo, Traversetti, in press.

11. The statements are as follows: "It happens to me that at a certain point I get lost and don't know what is being talked about"; "It happens to me that I imagine what will happen in the text after reading the title"; "I stop to look for the most important things in what I am reading "; "I try to guess the meaning of unknown words or phrases"; "It happens to me that I linger in the middle of the story to imagine how it will end"; "I underline the text to select the most important things"; "I think back in a few words what I have read, how far I have got"; "I re-read to make sure I have understood what I am reading"; "In my mind I summarize what I am reading "; "I look for other people to discuss with be-cause this allows me to better understand what I am reading” (La Marca, Di Martino, Gülbay, 2019).

\section{References}

Benvenuto, G. (1987). Insegnare a riassumere: proposte per un itinerario didattico di prove di riassunto. Torino: Loescher.

Bonaiuti, G. (2014). Le strategie didattiche. Roma: Carocci.

Borkowski, J.G., \& Muthukrishna, N. (2011). Didattica metacognitiva. Come insegnare strategie efficaci di apprendimento. Edizioni Erickson.
Boterf, G.L. (1995). De la compétence. Paris: Les Editions d'Organisation.

Cajola, L.C., \& Traversetti, M. (2016). Il metodo di studio come «prima misura compensativa» per l'inclusione degli allievi con DSA: progetto per una ricerca esplorativa sulle scelte inclusive della scuola primaria e secondaria di primo grado. Journal of Educational, Cultural and Psycholog- 
ical Studies (ECPS Journal), 1(14):127-151. DOI: https://doi.org/10.7358/ecps-2016-014chia

Cajola, L.C., \& Traversetti, M. (2018). Il metodo di studio a scuola per allievi con DSA nella prospettiva dell'ICF-CY. Dati di ricerca. Education sciences and society, 1:22-48. DOI: https://doi.org/10.3280/ess12018oa6120

Cajola, L.C., \& Traversetti, M. (2018). L'educatore professionale socio-pedagogico nei servizi educativi e scolastici tra sviluppo sostenibile e governance inclusiva: alcuni dati di ricerca. Journal of Educational, Cultural and Psychological Studies (ECPS Journal), 9(17):113-138. DOI: https://doi.org/10.7358/ecps-2018-017-chia

Calvani, A., \& Chiappetta, L.C. (Eds.) (2019). Strategie efficaci per la comprensione del testo. Il Reciprocal Teaching. Firenze: SApIE Scientifica.

Chall, J.S., \& Jacobs, V.A. (2003). The classic study on poor children's fourth-grade slump. American Educator, 27(1): 14-15. https://www.aft.org/periodical/americaneducator/spring-2003/classic-study-poorchildrens-fourth-grade-slump

Cohen, L., Manion, L., \& Morrison, K. (2007). Research methods in education. London and New York: Routledge.

Cornoldi, C., Colpo, G., \& Carretti, B. (2017). Prove MT-Kit scuola. Classi 3-4-5 primaria. Dalla valutazione degli apprendimenti di lettura e comprensione del testo al potenziamento. Firenze: Giunti Edu.

Council of the European Union (2018). Council recommendation of 22 May 2018 on key competences for lifelong learning. Retrieved March 30, 2021, from https://eur-

lex.europa.eu/legal-

con-

tent/EN/TXT/?uri=uriserv\%3AOJ.C_.2018.1 89.01.0001.01.ENG

Davis, D.S. (2013). Multiple comprehension strategies instruction in the inter-mediate grades: three remarks about content and pedagogy in the intervention literature. $R e$ view of Education, 1(2):194-224. DOI: https://doi.org/10.1002/rev3.3005
Dede, C. (2005). Why design-based research is both important and diffi-cult. Educational Technology, 45(1):5-8. https://www.jstor.org/stable/44429182?seq= 1

Delors, J. (1997). Rapporto all'UNESCO della Commissione Internazionale sull'Educazione per il Ventunesimo Secolo. Roma: Armando Editore.

Hattie J. (2017). Visible Learning plus. 250+ Influences on Student Achievement. Retrieved March 30, 2021, from https://visible-learning.org/wpcontent/uploads/2018/03/VLPLUS-252Influences-Hattie-ranking-DEC-2017.pdf

Hattie, J. (2009). Visible Learning: A Synthesis of over 800 Meta-Analyses Relating to Achievement. London: Routledge.

La Marca, A., Di Martino, V., Gülbay, E. (2019). Il questionario metacognitivo Qmeta. In A. Calvani, \& L. Chiappetta Cajola (a cura di). Strategie efficaci per la comprensione del testo. Il Reciprocal Teaching (479-487). Firenze: SApIE Scientifica.

Lee, S.H., \& Tsai, S.F. (2017). Experimental intervention research on students with specific poor comprehension: A systematic review of treatment out-comes. Reading and Writing, 30(4):917-943. DOI: https://doi.org/10.1007/s11145-016-9697-x

Lucisano, P., \& Salerni, A. (2002). Metodologia della ricerca in educazione e formazione. Roma: Carocci. Mitchell, D.

Mitchell, D. (2014). What really works in special and inclusive education. Using evidence-based teaching strategies. New York: Routledge.

MIUR. Ministry of Education, University and Research (2011). Guidelines for the right to study of students and students with specific learning disorders. Retrieved March 30, 2021, from https://files.eric.ed.gov/fulltext/ED591017.p df

NICHD. National Institute of Child Health and Human Development (2000). Report of the National Reading Panel. Teaching children to read: An evi-dence-based assessment of the scientific research literature on reading and its impli-cations for reading instruction 
(NIH Publication No. 00-4769). Washington, DC: U.S. Government Printing Office. Retrieved March 30, 2021, from

https://www.nichd.nih.gov/sites/default/files/ publications/pubs/nrp/Documents/report.pdf

Novak, J. D. (2001). L'apprendimento significativo: le mappe concettuali per creare e usare la conoscenza. Trento: Edizioni Erickson.

Nussbaum, M., \& Sen, A. (Eds.). (1993). The quality of life. Clarendon Press.

Nussbaum, M.C. (2011). Capabilities, entitlements, rights: Supplementation and critique. Journal of Human Development and Capabilities, 12(1):23-37. DOI: https://doi.org/10.1080/19452829.2011.5417 $\underline{31}$

Okkinga, M., van Steensel, R., Van Gelderen, A.J., \& Sleegers, P.J. (2018). Effects of reciprocal teaching on reading comprehension of low-achieving adolescents: The importance of specific teaching skills. Journal of Research in Reading, 41 (1):20-41. DOI: https://doi.org/10.1111/1467-9817.12082

Palincsar, A.S., \& Brown, A.L. (1984). Reciprocal teaching of comprehension fostering and comprehension-monitoring activities. Cognition and Instruction, 1(2):117-175. DOI: https://doi.org/10.1207/s1532690xci0102_1

Rizzo, A.L, Montesano, L., Traversetti, M. (2020). Come migliorare la comprensione del testo. Il programma Reading Comprehension-Reciprocal Teaching (RC-RT). Nuova Secondaria, n. 3, Anno XXXVIII, pp95-pp121. Retrieved March 30, 2021, from

https://polaris.unical.it/handle/20.500.11770/ 307239\#.YMLOLagzZm8

Rizzo, A.L., \& Traversetti, M. (2021). Understanding the text to study it: Specific learning disorders and inclusive and effective teaching strategies. Italian Journal of Educational Research, 26:88-104. https://doi.org/10.7346/sird-012021-p88

Rosenshine, B., \& Meister, C. (1994). Reciprocal teaching: A review of the re-search. Re- view of Educational Research, 64(4):479530. DOI:

https://doi.org/10.3102/00346543064004479

Sen, A. (1982). Poverty and famines: an essay on entitlement and deprivation. Oxford: Oxford University Press.

Sen, A. (1992). Inequality reexamined. Oxford University Press.

Sen, A. (1993). Capability and well-being 73. The quality of Life, 30:270-293. DOI: https://doi.org/10.1093/0198287976.001.000 1

Sen, A. (1999). Development as Freedom. Oxford: Oxford University Press.

Sen, A. (2000). Social exclusion: Concept, application, and scrutiny. Manila: Office of Environment and Social Development, Asian Development Bank.

Sen, A. (2001). Development as freedom. Oxford: Oxford Paperbacks.

Sen, A. K. (2009). The idea of justice. Harvard: Harvard University Press.

Simon, H.A. (1969). The science of the artefact. Cambridge: MIT press.

Sweller, J. (1988). Cognitive load during problem solving: Effects on learning. Cognitive Science, 12(2):257-285. DOI: https://doi.org/10.1016/03640213(88)90023-7

Traversetti, M., \& Rizzo, A.L. (2019). A proposito di efficacia. In A. Canevaro \& D. Ianes (a cura di), Un altro sostegno è possibile. Pratiche di evoluzione sostenibile ed efficace. Trento: Erickson.

Traversetti, M., RIZZO, A.L. (2020). Reciprocal teaching para estudiantes con discapacidad intelectual: una investigación empírica en la escuela italiana. In Caparrós Martín, E., Alcaráz Salarirche, N. RIZZO, A.L. (Coords.). Educación Inclusiva: un desafío y una oportunidad para la innovación educativa en la formación inicial del profesorado (pp83-pp99). Barcelona: Octaedro.

Trinchero, R. (2002). Manuale di ricerca educativa. Milano: FrancoAngeli. 
Rizzo \& Traversetti. Learning for Students with Specific Learning Disorder in Italy.

Received: 30 March 2021

Revised: 08 June 2021

Accepted: 08 June 2021 